\title{
Impairment of the myocardial vasomotor response to cold pressor stress in collateral dependent myocardium
}

Neal G Uren, Tom Crake, Dimitris Tousoulis, Charles Seydoux, Graham J Davies, Attilio Maseri

\begin{abstract}
Abotract
Objective-To otudy the vasomotor response (cold preasor/basal flow) in myocardlum porfused entrely by collaterale, uolng the reflex eympathetle etimulation of cold pressor etrees.

Design-Regional myocardlal blood flow was measured in collateral dependent and in remote myocardium using positron emission tomography with ${ }^{15} \mathrm{O}$ water at basal and at cold pressor stress. Regional ischaemia was measured with ${ }^{18}$ F-fluorodeoxyglucose (FDG).

Patients-Nine patients (mean (SD) age 53 (6) years) with an occluded coronary artery supplied entirely by collaterals from other angiographically normal arteries.

Resulte-In remote myocardium, basal and cold pressor flow were $0.99(0.26)$ and $1.46(0.60) \mathrm{m} / \mathrm{m} / \mathrm{n} / \mathrm{g} \quad(P<0.05)$, reupectively, a myocardial vasomotor response of $1.46(0.45)$. In collateral dependent myocardium, basal and cold pressor flow were $0.91(0.20)$ and $0.87(0.35) \mathrm{ml} / \mathrm{min} / \mathrm{g}$, respectively (the latter value, $P<0.05 v$ remote region), a myocardial vasomotor response of $0.97(0.43)(P<0.05 v$ remote region). The myocardial vascular resistance (mean arterial pressure/flow) during cold pressor was higher in the collateral dependent than in remote myocardium, at $147.0(61.1)$ and 85.6 (32.3) $\mathrm{mm} \mathrm{Hg} \cdot \mathrm{min} \cdot \mathrm{g} / \mathrm{ml}(\mathrm{P}<0 \cdot 05)$, respectively, but with no relative increase in FDG uptake.
\end{abstract}

Conclusions-In contrast to the decrease in myocardial resistance in remote myocardium with cold pressor, an increase was observed in collateral dependent myocardium suggesting a vasoconstrictor response in resistive vessels, without demonstrable myocardial ischaemia.

(Heart 1997;78:61-67)

Keywords: coronary resistive vessels; cold pressor stress; myocardial blood flow; positron emission tomography; vasoconstriction

After coronary artery occlusion, there is often no myocardial necrosis in the jeopardised region because collateral blood flow from other myocardial regions is sufficient to maintain basal perfusion and thus myocardial viability. ${ }^{12}$ Animal studies have shown that flow to an ischaemic zone through native collaterals may even approach $30-50 \%$ of normal values, implying minimal coronary redistance only two to three times normal. ${ }^{34}$ Although radiolmag Ing studies have indicated normal myocardial perfudion in collateral dependent areas at reot and on exertion, ${ }^{5=7}$ one study using positron emission tomography has shown a reduced coronary vasodilator response to dipyridamole in collateral dependent myocardium. ${ }^{8}$ Furthermore, during atrial pacing, regional wall motion abnormalities develop in the myocardial segments perfused by collateral vessels, ${ }^{2}$ indicating a limitation of the capacity of the collateral vessels to maintain adequate myocardial perfusion in the face of increased myocardial metabolic requirements.

It has been suggested that in patients with coronary disease, changes in vasomotor tone at the level of the coronary collateral and resistive vessels may alter the ischaemic threshold. ${ }^{9}$ Several other groups have suggested that this functional abnormality of the coronary collateral and resistive vessels, which appears to occur as part of the atherosclerotic process, may lead to an altered sensitivity to sympathetic activation. ${ }^{10-12}$ This may be manifest by these vessels showing either an inability to vasodilate adequately or an inappropriate vasoconstriction, with the potential for the development of myocardial ischaemia. Myocardial blood flow in collateral dependent myocardium may thus serve as a model of resistive vessel function. ${ }^{13}$

To study the vasomotor response of the collateral and resistive vessels, we investigated myocardial perfusion in a group of patients with normal left ventricular function and one occluded coronary artery (a region thus entirely dependent on collateral blood flow), using oxygen-15 labelled water $\left(\mathrm{H}_{2}{ }^{15} \mathrm{O}\right)$ as a flow tracer at positron emission tomography (PET). Cold pressor stress was used as a sympathetic nervous system stimulus to induce a vasomotor response, after intact vasomotor responses to different non-invasive stimuli were established. Regional glucose metabolism using fluorine-18 labelled fluoro-deoxyglucose $\left({ }^{18} \mathrm{FDG}\right)$ was also measured to show the presence or absence of recent transmural ischaemia in the collateral dependent region. ${ }^{14}$

\section{Methods}

PATIENTS

Nine patients (mean (SD) age 53 (6) years, seven male, two female) with a single coronary artery occlusion were selected for study within 
Table 1 Global and regional left ventriculography

\begin{tabular}{|c|c|c|c|c|c|c|c|c|c|}
\hline \multirow[b]{2}{*}{ Patient } & \multirow[b]{2}{*}{ Age/sex } & \multirow[b]{2}{*}{$\begin{array}{l}\text { Occluded } \\
\text { artery }\end{array}$} & \multirow[b]{2}{*}{$\begin{array}{l}\text { Collateral } \\
\text { grade }\end{array}$} & \multirow{2}{*}{$\begin{array}{l}L V \\
\text { ejection } \\
\text { fraction } \\
(\%)\end{array}$} & \multicolumn{5}{|c|}{ Regional wall motion (\% of contribution) } \\
\hline & & & & & $\begin{array}{l}\text { Antero-basal } \\
(14 \cdot 4 \text { to } 24 \cdot 4)\end{array}$ & $\begin{array}{c}\text { Antero-lateral } \\
(10 \cdot 1 \text { to } 17 \cdot 3)\end{array}$ & $\begin{array}{l}\text { Apical } \\
(2 \cdot 5 \text { to 6.3) }\end{array}$ & $\begin{array}{l}\text { Inferior } \\
(10.6 \text { to } 18.2)\end{array}$ & $\begin{array}{l}\text { Postero-basal } \\
(15 \cdot 7 \text { to } 25 \cdot 4)\end{array}$ \\
\hline $\begin{array}{l}1 \\
2 \\
3 \\
4\end{array}$ & $\begin{array}{l}56 / M \\
63 / F \\
56 / M \\
43 / F\end{array}$ & $\begin{array}{l}\text { RCA } \\
\text { RCA } \\
\text { LAD } \\
\text { RCA }\end{array}$ & $\begin{array}{l}\text { G3-LCX } \\
\text { G2-LCX } \\
\text { G2-LCX } \\
\text { G3-LAD } \\
\text { G3-LCX }\end{array}$ & $\begin{array}{l}82 \cdot 3 \\
70.9 \\
81 \cdot 5 \\
86.4\end{array}$ & $\begin{array}{l}20 \cdot 3 \\
16 \cdot 5 \\
21 \cdot 3 \\
23 \cdot 5\end{array}$ & $\begin{array}{l}16 \cdot 7 \\
12 \cdot 2 \\
18 \cdot 0 \\
17 \cdot 5\end{array}$ & $\begin{array}{l}4 \cdot 2 \\
4 \cdot 9 \\
4 \cdot 8 \\
4 \cdot 5\end{array}$ & $\begin{array}{l}15 \cdot 8 \\
18 \cdot 1 \\
17 \cdot 8 \\
16 \cdot 5\end{array}$ & $\begin{array}{l}25 \cdot 2 \\
19 \cdot 2 \\
19 \cdot 4 \\
24 \cdot 4\end{array}$ \\
\hline 5 & $48 / M$ & RCA & $\begin{array}{l}\text { G2-LCX } \\
\text { G3-RCA }\end{array}$ & $75 \cdot 8$ & $21 \cdot 0$ & $17 \cdot 1$ & $5 \cdot 2$ & $15 \cdot 8$ & $16 \cdot 7$ \\
\hline $\begin{array}{l}6 \\
7\end{array}$ & $\begin{array}{l}\text { 51/M } \\
56 / M\end{array}$ & $\begin{array}{l}\text { LCX } \\
\text { LAD }\end{array}$ & $\begin{array}{l}\text { G3-RCA } \\
\text { G2-RCA } \\
\text { G2-LAD }\end{array}$ & $\begin{array}{l}64.9 \\
76.5\end{array}$ & $\begin{array}{l}18 \cdot 1 \\
20 \cdot 5\end{array}$ & $\begin{array}{l}12.9 \\
15.6\end{array}$ & $\begin{array}{l}4 \cdot 2 \\
4 \cdot 0\end{array}$ & $\begin{array}{l}14 \cdot 2 \\
13 \cdot 6\end{array}$ & $\begin{array}{l}15 \cdot 5 \\
22 \cdot 8\end{array}$ \\
\hline $\begin{array}{l}8 \\
9 \\
\text { Mean (SD) }\end{array}$ & $\begin{array}{l}56 / M \\
51 / M\end{array}$ & $\begin{array}{l}\text { LCX } \\
\text { LAD }\end{array}$ & $\begin{array}{l}\text { G3-RCA } \\
\text { G3-RCA }\end{array}$ & $\begin{array}{l}68 \cdot 8 \\
67 \cdot 9 \\
75 \cdot 0(7 \cdot 4)\end{array}$ & $\begin{array}{l}21 \cdot 2 \\
21 \cdot 4 \\
20 \cdot 4(2 \cdot 0)\end{array}$ & $\begin{array}{l}18 \cdot 0 \\
10 \cdot 7 \\
15 \cdot 4(2 \cdot 8)\end{array}$ & $\begin{array}{l}5 \cdot 0 \\
3.0 \\
4 \cdot 4(0 \cdot 7)\end{array}$ & $\begin{array}{l}10 \cdot 7 \\
12 \cdot 8 \\
15 \cdot 0(2 \cdot 4)\end{array}$ & $\begin{array}{l}14 \cdot 0 \\
20 \cdot 1 \\
19 \cdot 7(3.9)\end{array}$ \\
\hline
\end{tabular}

The normal ranges of regional contribution to left ventricular function are in parentheses. Collaterals are graded (G) according to the method of Rentrop et al ${ }^{15}$ with the artery of origin of the collateral vessels. LV, left ventricular; LAD, left anterior descending artery; LCX, left circumflex artery; RCA, right coronary artery.

four weeks of routine cardiac catheterisation for symptoms of recurrent exertional chest pain. No patient had electrocardiographic (ECG) evidence of previous myocardial infarction-specifically an absence of pathological $Q$ waves on 12-lead ECG-and all patients had stable symptoms and normal left ventricular function (table 1). Patients were selected who did not have a clinical history of hypertension, left ventricular hypertrophy, or diabetes mellitus. All had a positive exercise test $(0.1 \mathrm{mV}$ ST segment depression, defined as the ischaemic threshold) at moderate workload on the modified Bruce protocol.

PROTOCOL

The study was approved by the research ethics committee of Hammersmith Hospital and all patients gave informed and written consent. Patients were studied on three separate occasions within a two week period after selection for study at the time of coronary arteriography. Anti-anginal drugs were discontinued at least 48 hours before any part of the study. To document the presence of exercise induced myocardial ischaemia and the response to nitrates, symptom limited maximum exercise testing was performed under basal conditions and after $0.5 \mathrm{mg}$ sublingual glyceryl trinitrate in random order. On a second occasion, non-invasive stress testing was performed. The stress tests used were: mental arithmetic (serial 7 subtraction for up to five minutes); hand grip (to $30 \%$ maximum grip for up to five minutes); and cold pressor (immersion of the right hand in ice for as long as tolerated, or for up to six minutes). These stress tests were done to demonstrate an intact systemic blood pressure response to different afferent stimuli. They were performed with continuous ECG monitoring, and 12-lead ECG and blood pressure recordings were made every minute of the test. On the third occasion, patients underwent PET under basal conditions and during cold pressor stress.

\section{CORONARY ARTERIOGRAPHY AND} VENTRICULOGRAPHY

All patients selected had a proximal occlusion of a single vessel, with no evidence of bridging collaterals at the site of the coronary occlusion. Intercoronary collaterals were visualised in all patients and were graded according to the method of Rentrop et $a l,,^{15}$ where $0=$ none, 1 = filling of side branches without visualisation of the epicardial segment, 2 = partial filling of the epicardial segment via collateral channels, and $3=$ complete filling of the epicardial segment (table 1). Nitrates were not given during coronary arteriography to avoid changes in intercoronary collateral flow.

Global and regional left ventricular ejection fraction was measured from the $30^{\circ}$ right anterior oblique left ventricular cine-angiogram with an automated hard wired endocardial contour detector, and linked to a microcomputer (Cardiovascular Angiographic Analysis System (CAAS), Pie Medical Equipment BV, Maastricht, The Netherlands). ${ }^{16}$ The range for normal global ejection fraction using this method is $53-93 \% .{ }^{16}$ No regional wall motion abnormalities were noted using this technique.

MEASUREMENT OF REGIONAL BLOOD FLOW AND METABOLISM

Patients were fasted overnight and all had been off anti-anginal drugs (except for sublingual nitrates) for at least $\mathbf{4 8}$ hours. No nitrates were taken for at least two hours before the study. All PET scans were performed with an ECAT 93108/12 camera (CTI Inc, Knoxville, Tennessee, USA). ${ }^{17}$ Regional myocardial blood flow $\left(\mathrm{ml} / \mathrm{min} / \mathrm{g}\right.$ ) was measured using $\mathrm{H}_{2}{ }^{15} \mathrm{O}$ as a flow tracer using the previously validated $\mathrm{C}^{15} \mathrm{O}_{2}$ inhalation technique. ${ }^{18}$ Measurements were made at basal and during the cold pressor stress. The protocol during the cold pressor test was as follows: after a background scan of 30 seconds, the right hand was immersed in ice simultaneously with the start of $\mathrm{C}^{15} \mathrm{O}_{2}$ inhalation, which was given for 210 seconds. The hand was removed from ice between the end of $\mathrm{C}^{15} \mathrm{O}_{2}$ inhalation and the end of the scan at 420 seconds. Systemic blood pressure and heart rate were monitored throughout the study and a 12-lead ECG was recorded every minute during the stress.

Immediately following the cold pressor stress, $185 \mathrm{MBq} / \mathrm{ml}$ of ${ }^{18} \mathrm{FDG}$ was given by intravenous infusion ( $5 \mathrm{ml}$ over five minutes), and a dynamic scan acquired over 65 minutes. Data analysis was done over the last 10 minutes of scanning. Under ischaemic conditions, there is an increased utilisation of glucose by the myocardium, both from glycogen breakdown 
and from exogenous glucose uptake. FDG shares the same trans-sarcolemmal carrier with glucose and is converted to deoxyglucose-6phosphate, which is not metabolised further and accumulates in the cell in proportion to exogenous glucose utilisation. ${ }^{19}$ Previous work has shown an increased FDG uptake persisting for up to three hours in post-ischaemic myocardium. ${ }^{14}$ In this study, regional FDG uptake was measured in absolute counts of activity (counts/s/pixel). ${ }^{20}$

\section{ANALYSIS OF PET DATA}

The sinograms were corrected for attenuation and reconstructed on a Microvax II computer (Digital Equipment Corporation, Marlboro, Massachusetts, USA). ${ }^{16} 17$ Images were transferred to a SUN 3/60 work station (SUN Microsystems, Menlo Park, California, USA) for further analysis using Analyze (Mayo Foundation, Rochester, Minnesota, USA) and Pro-Matlab (The Mathworks Inc, South Natick, Massachusetts, USA) software packages. Images were created and analysed as previously described. ${ }^{18}$ The myocardium was divided into four equally sized regions: septal, anterior, lateral, and infero-posterior. In patients with the left anterior descending coronary artery as the occluded artery, the anterior region was designated as the collateral dependent region and the infero-posterior region as the remote region of interest. In patients with a dominant right coronary artery or left circumflex coronary artery as the occluded artery, the infero-posterior region was designated as the collateral dependent region and the anterior region as the remote region of interest. Remote regions were chosen so as not to be in continuity with the region supplied by the occluded artery. For the purpose of measuring flow in the area of myocardium supplying collateral vessels, the epicardial artery in question was cross correlated with one of the remaining three regions by PET analysis, adjacent to the collateral dependent region.

Basal myocardial blood flow and myocardial blood flow during cold pressor were determined. The myocardial vasomotor response was defined as: cold pressor flow/basal flow. This index was a measure of the ability of the microcirculation to vasodilate in response to the $\alpha$ adrenergic stimulus of the cold pressor stress. To exclude the effect of changes in coronary perfusion pressure on myocardial flow, regional myocardial vascular resistance was calculated as: mean arterial pressure/myocardial blood flow, both under basal conditions and during cold pressor, and subsequently expressed as $\mathrm{mm} \mathrm{Hg} \cdot \mathrm{min} \cdot \mathrm{g} / \mathrm{ml}$. To express these values as a relative index of vasodilatation (value $<1$ ) or vasoconstriction (value $>1$ ), a myocardial resistance reserve was also derived as: myocardial resistance at cold pressor/myocardial resistance under basal conditions.

\section{STATISTICAL ANALYSIS}

Results are expressed as mean (SD). Data were analysed using the paired and unpaired Student $t$ test as appropriate. Simultaneous comparison of more than two mean values was performed using one way analysis of variance (ANOVA), and Fisher's least significant difference method was subsequently applied to localise the source of the difference. A P value less than 0.05 was considered statistically significant.

\section{Results}

EXERCISE TESTING

At enrolment to the study, patients underwent exercise testing under normal conditions and after sublingual nitrates. Rate-pressure product was similar at rest (10860 (2240) v 11630 (2420) $\mathrm{mm} \mathrm{Hg} / \mathrm{min}$ ), and at peak exercise (24890 (5940) v 25400 (5740) $\mathrm{mm} \mathrm{Hg} / \mathrm{min})$ before and after nitrates, respectively. All nine patients had positive tests under basal conditions (0.1 mV ST segment depression); after sublingual nitrates, two patients had a negative test. In the remaining seven patients, the ischaemic threshold increased significantly because of an increase in heart rate at this point (19650 (3690) v 23100 (5340) $\mathrm{mm} \mathrm{Hg} / \mathrm{min}$, $P<0.05)$. On comparing exercise times, there was an increase in time to peak exercise from 889 (116) to 931 (106) seconds $(P<0.05)$, comparing without and with nitrate administration, respectively. In the seven patients who had positive tests after sublingual nitrate, the time to the ischaemic threshold increased from 653 (173) to 769 (148) seconds $(P<0.05)$, comparing without and with nitrates, respectively.

\section{NON-INVASIVE STRESS TESTING}

Mental stress, isometric hand grip, and cold pressor stress had no significant effect on heart rate, but all three increased systolic blood pressure and thus the rate-pressure product (table 2). Mental stress caused only a small increase in mean arterial pressure compared to basal. However, isometric hand grip and cold pressor had marked effects on increasing both diastolic and mean arterial pressure. There were no significant $S T$ segment changes $(0.1 \mathrm{mV}$ depression) with any of the non-invasive tests in any of the patients. There was no chest pain with

Table 2 Haemodynamic variables at non-invasive stress testing, mean (SD)

\begin{tabular}{|c|c|c|c|c|c|c|c|c|c|c|}
\hline & \multicolumn{5}{|l|}{ Basal } & \multicolumn{5}{|c|}{ Maximum values } \\
\hline & $\begin{array}{l}\text { Heart } \\
\text { rate }\end{array}$ & $\begin{array}{l}\text { Systolic } \\
\text { blood } \\
\text { pressure } \\
(\mathrm{mm} \mathrm{Hg})\end{array}$ & $\begin{array}{l}\text { Diastolic } \\
\text { blood } \\
\text { pressure } \\
\text { (mm } \mathrm{Hg})\end{array}$ & $\begin{array}{l}\text { Mean } \\
\text { arterial } \\
\text { pressure } \\
(\mathrm{mm} \mathrm{Hg})\end{array}$ & $\begin{array}{l}\text { Rate-pressure } \\
\text { product } \\
\text { (mm } \mathrm{Hg} / \mathrm{min})\end{array}$ & $\begin{array}{l}\text { Heart } \\
\text { rate }\end{array}$ & $\begin{array}{l}\text { Systolic } \\
\text { blood } \\
\text { pressure } \\
(\mathrm{mm} \mathrm{Hg})\end{array}$ & $\begin{array}{l}\text { Diastolic } \\
\text { blood } \\
\text { pressure } \\
(\mathrm{mm} \mathrm{Hg})\end{array}$ & $\begin{array}{l}\text { Mean } \\
\text { arterial } \\
\text { pressure } \\
(\mathrm{mm} \mathrm{Hg})\end{array}$ & $\begin{array}{l}\text { Rate-pressure } \\
\text { product } \\
\text { (mm Hg/min) }\end{array}$ \\
\hline $\begin{array}{l}\text { Mental stress } \\
\text { Handgrip } \\
\text { Cold pressor }\end{array}$ & $\begin{array}{l}75(11) \\
71(11) \\
70(9)\end{array}$ & $\begin{array}{l}128(20) \\
124(20) \\
119(22)\end{array}$ & $\begin{array}{l}85(12) \\
84(15) \\
82(12)\end{array}$ & $\begin{array}{l}99(14) \\
98(16) \\
95(15)\end{array}$ & $\begin{array}{l}9572(2095) \\
7637(3077) \\
8252(1886)\end{array}$ & $\begin{array}{l}78(10) \\
76(10) \\
71(10)\end{array}$ & $\begin{array}{l}138(24)^{\star \star} \\
151(32)^{\star \star} \\
152(33)^{\star \star}\end{array}$ & $\begin{array}{l}86(10) \\
97(19)^{\star} \\
96(14)^{\star \star}\end{array}$ & $\begin{array}{l}103(14)^{\star} \\
115(23)^{\star \star} \\
114(19)^{\star \star}\end{array}$ & $\begin{array}{l}10749(2277)^{\star \star} \\
11445(2995)^{\star \star} \\
10717(2714)^{\star \star}\end{array}$ \\
\hline
\end{tabular}


Figure 1 Individual data points depicting the myocardial blood flow at basal and cold pressor in collateral dependent and remote regions. $* P<0.05$.

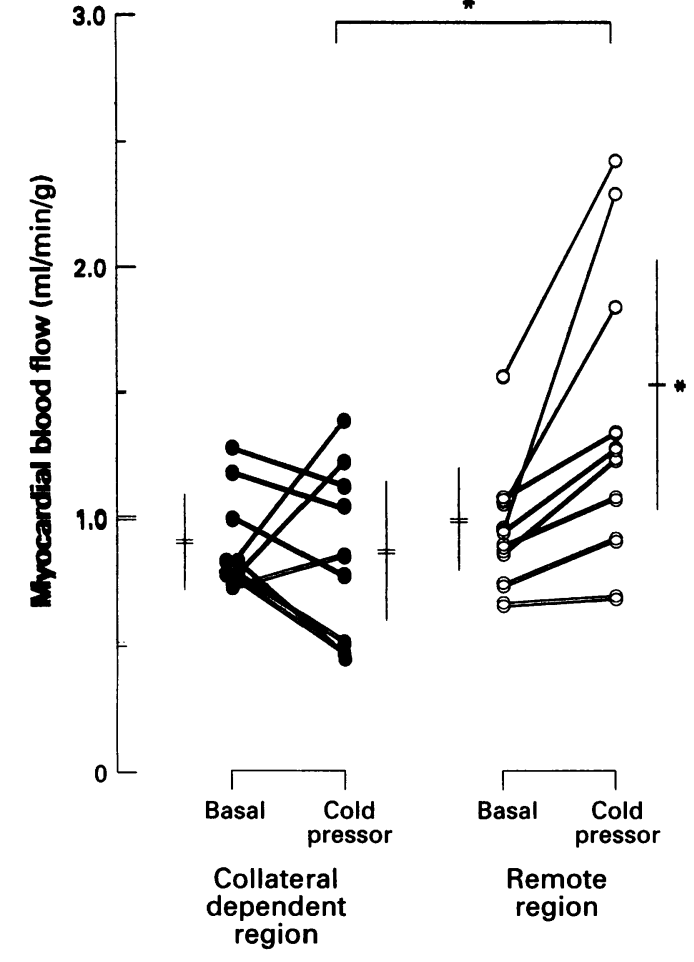

mental stress or hand grip, but two patients reported mild chest pain during cold pressor stress.

POSITRON EMISSION TOMOGRAPHY

Cold pressor stress was sustained for a mean duration of 5.7 minutes (range 4 to 6.5) at PET scanning. Cold pressor increased systolic blood pressure, from 117 (19) to 153 (31) $\mathrm{mm} \mathrm{Hg} \mathrm{(P}$ $<0.01$ ) and rate-pressure product, from 7380 (1710) to 10380 (3150) $\mathrm{mm} \mathrm{Hg} / \mathrm{min}$ ( $\mathrm{P}<$ 0.01 ) at basal and cold pressor, respectively, but had no significant effect on heart rate (63 (7) to 67 (11) beats/min, NS). The mean arterial pressure increased from 95 (16) to 114

Figure 2 Individual data points depicting the points depicting the resistance at basal and cold pressor in collateral dependent and remote regions. ${ }^{*} P<0.05$.

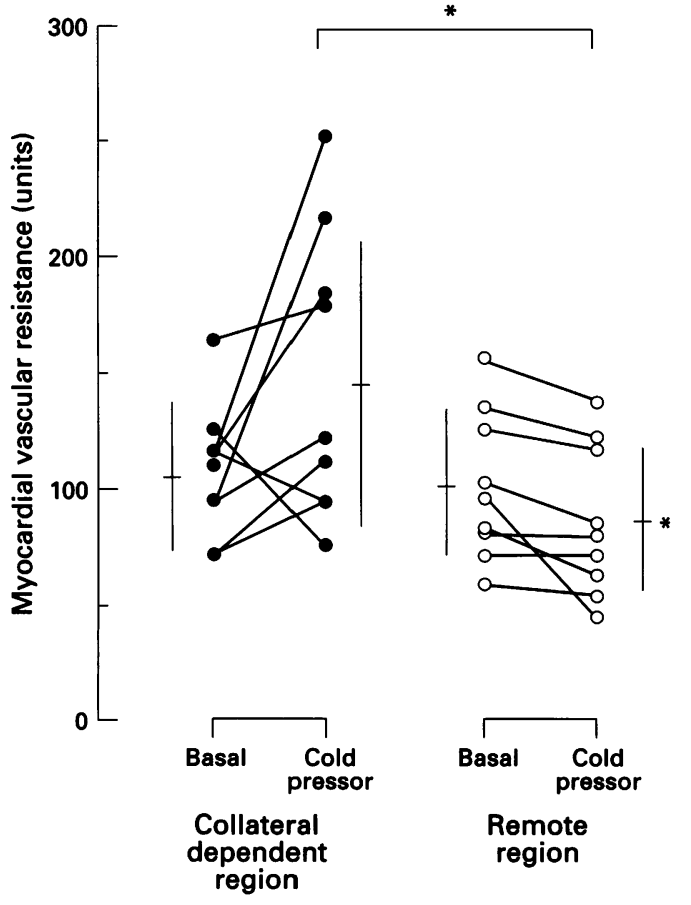

(20) $\mathrm{mm} \mathrm{Hg}(P<0.01)$ with cold pressor. Two patients reported chest pain during cold pressor but no significant ST segment changes were observed in any patient.

In the remote region, basal and cold pressor flow were $0.99(0.26)$ and $1.46(0.60) \mathrm{ml} / \mathrm{min} / \mathrm{g}$ ( $\mathrm{P}<0.05 v$ basal flow), respectively, a myocardial vasomotor response of $1.46(0.45)$. In the collateral dependent region, basal and cold pressor flow were $0.91(0.20) \quad(P=N S v$ remote region) and $0.87(0.35) \mathrm{ml} / \mathrm{min} / \mathrm{g}(P=$ NS $v$ basal flow, $P<0.05 v$ remote region), respectively, a myocardial vasomotor response of $0.96(0.43)$ ( $P<0.05 v$ remote region) (fig 1). In the remote reston, the myocardial vascular realotance decreased from $100.7(31.7)$ to $85.6(32.3) \mathrm{mm} \mathrm{Hg} \cdot \mathrm{min} \cdot \mathrm{g} / \mathrm{ml} \quad(P<0.05)$ 䬺 basal and cold pressor, respectively, In the collateral dependent region, the myocardial vascu= lar resistance was $107.6(28.4) \mathrm{mm} \mathrm{Hg} \cdot \mathrm{min} \cdot \mathrm{g} /$ $\mathrm{ml}$ at basal $(\mathbf{P}=\mathrm{NS} v$ remote region), increasing to $147 \cdot 0(61 \cdot 1) \mathrm{mm} \mathrm{Hg} \cdot \mathrm{min} \cdot \mathrm{g} / \mathrm{ml}$ at cold pressor $(\mathbf{P}=\mathrm{NS} v$ basal, $\mathbf{P}<0.05 v$ remote region) (fig 2). From this, a myocardial resistance reserve of $0.85(0.16)$ and $1.41(0.57)$ was derived in the remote and collateral dependent regions, respectively $(P<0.05)$.

A direct relation was seen between the increase in rate-pressure product with cold pressor and the myocardial vasomotor response in the remote region (fig 3), but not in the collateral dependent myocardium. No relation was shown between flow in the remote and collateral dependent regions either under basal conditions or at cold pressor. Furthermore, no relation was seen between the change in flow in myocardium supplying angiographic collaterals directly to the collateral dependent region with the change in flow in the latter region, excluding the possibility of inter-regional steal as the mechanism for the reduction in collateral flow (fig 4). Despite the increase in myocardial resistance with cold pressor stress in the collateral dependent myocardium, this occurred at a ratepressure product below that of the ischaemic threshold on exercise.

No regional increase in FDG uptake was seen in collateral dependent regions compared with remote regions: 1295 (970) (range 583 to

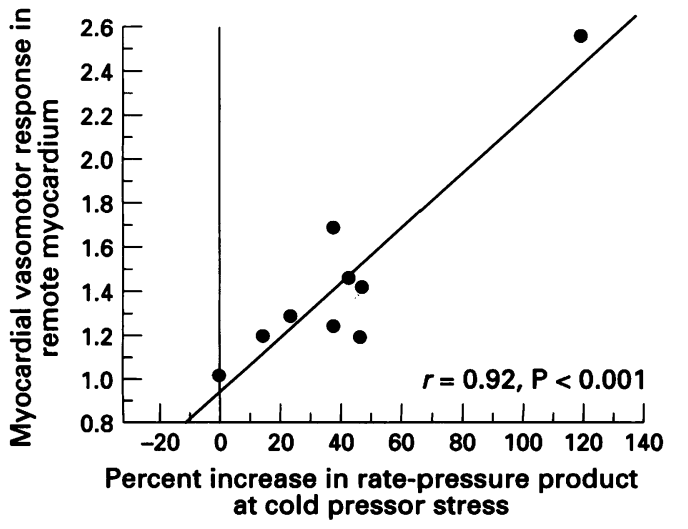

Figure 3 Scatterplot depicting the relation between the percent change in rate-pressure product with cold pressor stress and the myocardial vasomotor response in remote myocardium $(y=0.012 x+0.95)$. 
Figure 4 Scatterplot depicting the relation between the percent change in myocardial blood flow to collateral dependent myocardium and in myocardium supplying angiographic collaterals from the basal state to cold pressor. $M B F$, myocardial blood flow.

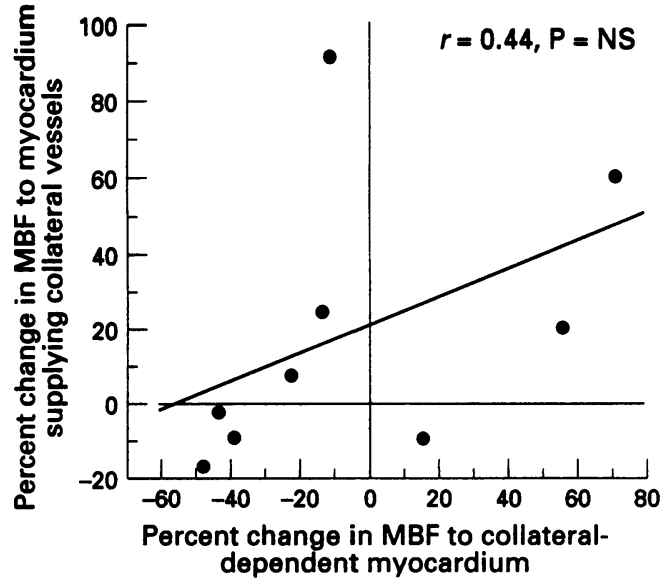

3382) $v 1342$ (972) (range 653 to 3336) counts/s/pixel, respectively, after cold pressor. Two patients (Nos 7 and 9) had a negative exercise test for ischaemia following sublingual nitrate, as reported above. However, myocardial blood flow at basal, after cold pressor, and the myocardial vasomotor response in collateral dependent or remote myocardium was not significantly different compared to the remaining patients with persistent exercise induced ischaemia.

The response to vasodilator stress at PET has been reported previously from our institution in five of these patients. ${ }^{8}$ In this previous study, the flow response to intravenous dipyridamole was measured in collateral dependent and remote myocardium using the same scanning protocol and method of analysis. As in this study, basal flow was comparable in both regions of interest. At maximum hyperaemia, the vasodilator response was reduced in collateral dependent regions, giving a flow reserve of $1.9(1.0)$ in collateral dependent myocardium compared to $3 \cdot 1(1 \cdot 1)$ in remote regions. ${ }^{8}$ On direct comparison of our current data with these results, no relation was found between the vasomotor response to dipyridamole and to cold pressor in collateral dependent or remote myocardium.

\section{Discussion}

In this study, there was no difference between the basal myocardial blood flow in the collateral dependent myocardium and in remote myocardium, indicating that the collateral vessels were sufficient to maintain resting myocardial perfusion. The reflex sympathetic stimulation of cold pressor resulted in a significant increase in flow in the remote but not in the collateral dependent myocardium, where mean flow remained unchanged. The vasomotor response to this stress in remote myocardium was directly related to the increase in myocardial work induced by this stimulation. There was an overall increase in myocardial vascular resistance in collateral dependent myocardium with cold pressor stress when compared to the remote region. However, there was no difference in regional FDG uptake comparing the two regions, suggesting the absence of significant transmural myocardial ischaemia as a consequence of this inappropriate vasoconstriction.

Cold pressor stress caused no demonstrable myocardial ischaemia. However, the peak ratepressure product achieved was lower than the ischaemic threshold determined at exercise testing. At exercise testing, all patients showed reversible myocardial ischaemia, indicating an inability of the collateral vessels to adequately increase coronary flow to match myocardial demand, consistent with previous findings. ${ }^{8}$ However, despite the absence of angiographic disease in the arteries subtending the collateral vessels, the time to, and cardiac workload at, $0.1 \mathrm{mV}$ ST segment depression still increased after sublingual nitrate, presumably through its effect on the coronary and systemic circulation, ${ }^{21}$ and on collateral blood flow. ${ }^{22}$

\section{SYMPATHETIC ACTIVATION AND THE}

\section{COLLATERAL MICROCIRCULATION}

The provocative stress of the cold pressor test induces reflex sympathetic activation with an increase in circulating catecholamines and both $\alpha$ and $\beta$ adrenergic neurally mediated effects in the coronary vascular bed. ${ }^{1011}$ In normal arteries, there is epicardial vasodilatation with an increase in coronary flow, whereas in atheromatous vessels, there is epicardial vasoconstriction and a reduction in coronary flow. ${ }^{11}$ It is likely that this vasoconstriction in atheromatous vessels is mediated predominantly through an unopposed action of the $\alpha$ adrenergic component of the sympathetic system on the coronary resistive vessels, ${ }^{10}$ possibly because of a reduction in the release of endothelium derived relaxing factors. ${ }^{11}{ }^{23}$ There is experimental evidence in animals to suggest that $\alpha$ adrenergic mechanisms may not necessarily modulate collateral vasomotion. Both methoxamine (an $\alpha_{1}$ adrenergic agonist) and clonidine (an $\alpha_{2}$ adrenergic agonist) reduced coronary flow in normal myocardium but without an effect on transcollateral resistance, and thus on collateral flow to a region subtended by collaterals. ${ }^{24}$ Others have shown that although noradrenaline (combined $\alpha_{1}$ and $\alpha_{2}$ adrenergic agonist) did not alter transcollateral resistance in an open chest dog model, selective $\alpha_{2}$ adrenergic stimulation alone with the agonist BHT920 did increase transcollateral resistance, ${ }^{25}$ perhaps implying an $\alpha_{2}$ adrenergic component to the modulation of collateral vasomotion. This is consistent with the finding that the predominant $\alpha$ adrenergic receptor in the coronary microcirculation is the $\alpha_{2}$ receptor. ${ }^{26}$ In contrast, mature collaterals have functional $\beta$ adrenergic receptors to a similar extent to other coronary vessels; increased $\beta$ adrenergic stimulation causes vasodilatation, thus improving collateral perfusion at times of stress. ${ }^{27}$

\section{COLLATERAL VASOMOTION AND RESISTIVE VESSEL FUNCTION}

Previous work has shown that infusion of noradrenaline ${ }^{28}$ and serotonin ${ }^{29}$ constrict resistive vessels larger than $100 \mu \mathrm{m}$, but dilate smaller vessels, confirming the functional heterogeneity of resistive vessels. ${ }^{30}$ We suggest that the local vasoconstrictor response to cold 
pressor in the collateral dependent region is an increased response to $\alpha$ adrenergic stimulation by the pre-arteriolar resistive vessels perfused by the collaterals. ${ }^{31} \mathrm{~A}$ major component of this impaired vasomotor response with sympathetic activation may be endothelial dysfunction in chronically perfused mature collaterals. This has been suggested by the specific vasoconstrictor response of resistive vessels in collateral dependent myocardium in open chest dogs to physiological doses of vasopressin leading to myocardial ischaemia. ${ }^{32}$ Using in vitro microvessel imaging, relaxation to the endothelium dependent vasodilators acetylcholine and ADP is markedly impaired in resistive vessels from collateral dependent myocardium compared to control myocardium. ${ }^{33}$ Chronic hypoperfusion through collaterals may alter endothelial regulation of arteriolar tone, ${ }^{23}$ through collateral vessels downregulating nitric oxide synthetase coupled to membrane receptors or growth factors from collateral vessels, causing proliferation of functionally less active resistive vessel endothelium. ${ }^{27}$ Furthermore, because of this reduction in coronary perfusion pressure at the origin of the resistive vessels, they may be more dilated in the basal state with any constriction having a larger net effect on resultant myocardial perfusion. ${ }^{32}$

Our findings rule out the possibility that the lack of change in myocardial blood flow in the collateral dependent myocardium with cold pressor could also be a collateral steal effect. Thus we found no relation between the change in cold pressor flow or resistance in collateral dependent myocardium and that in myocardium either completely remote or supplying collateral vessels to the former. This shows that the lack of increase in collateral flow cannot be explained on the basis of coronary blood flow steal, as suggested by previous animal studies. ${ }^{34} 35$

\section{STUDY LIMITATIONS}

A potential source of error lies in the accuracy of defining a myocardial region of interest as truly representative of the area under study. This may lead to the inclusion of areas of normal myocardium as well as the collateral dependent region. However, not only did we take great care to define the myocardial region in relation to the appearance of the coronary tree with collaterals at angiography, but this potential error would also tend to diminish the difference between the collateral dependent and remote myocardium. To avoid the converse effect of collateral dependent myocardium being included with normal myocardium, the remote region of interest was always diametrically opposite to the collateral dependent region.

The region of interest supplying collateral vessels is difficult to define accurately and although chosen as that adjacent to the collateral dependent region, it is likely that not all collateral vessels were circumscribed in this region. Also, although PET scanning was sensitive enough to exclude inter-regional steal as a potential mechanism, it does not exclude more subtle changes in intraregional perfusion occurring at the time of cold pressor stress.

Another limitation is the relatively small number of patients studied, reflecting the relative rarity of patients with an area of myocardium entirely dependent on collateral vessels for perfusion but with no evidence of previous infarction and with normal regional wall motion and collateral vessels arising from angiographically normal coronary arteries. The non-obstructed epicardial arteries supplying collaterals are described as normal on the basis of angiographic appearance, as no intravascular ultrasound studies were performed. However, even if there were a net vasoconstrictor effect with cold pressor in these epicardial vessels, ${ }^{11}$ this minor reduction in lumen cross sectional area would be unlikely to have any significant effect on coronary blood flow and thus myocardial perfusion in the collateral dependent area.

Previous work has shown that regional variations in FDG uptake may occur without concomitant changes in oxidative metabolism or perfusion which can limit the ability of the technique to exclude myocardial ischaemia. ${ }^{36}$ It remains possible that subendocardial ischaemia could occur through this inappropriate response to cold pressor stress but was not detected because of this reduction in sensitivity or through limitation of tissue resolution with this generation of PET scanner.

\section{CONCLUSIONS}

There is an impaired myocardial vasomotor response to the reflex sympathetic stimulation of cold pressor in myocardial regions entirely perfused by collateral vessels, with normal basal flow and contractile function at rest. This results in an increase in myocardial vascular resistance, that is, vasoconstriction, when compared to myocardium perfused by a non-diseased epicardial vessel. Although this abnormality in itself is unassociated with detectable signs of myocardial ischaemia using FDG uptake as a marker, it could contribute to the development of ischaemia in the presence of an increased myocardial oxygen demand or a reduced coronary perfusion pressure.

NGU was supported by a junior fellowship from the British Heart Foundation.

1 Frye R, Gurah GM, Chesebro JH, Ritman EL. Complete occlusion of the left main coronary artery and the importance of coronary collateral circulation. Mayo Clin Proc 1977;52:742-7.

2 Schwartz F, Flameng W, Ensslen R, Sesto M, Thormann J Effect of collaterals on left ventricular function at rest and during stress. Am Heart $\mathcal{\exists} 1978 ; 95: 570-7$.

3 Becker LC, Pitt B. Collateral blood flow in conscious dogs with chronic coronary artery occlusion. Am $\mathcal{F}$ Physiol 1971;221:1507-15.

4 Marcus ML, Kerber RE, Ehrhardt J, Abboud FM. Three dimensional geometry of acutely ischemic myocardium. Circulation 1975;52:254-61.

5 Rigo P, Becker LC, Griffith LSC, Alderson PO, Bailey IK Pitt B, et al. Influence of coronary collateral vessels on the result of thallium-201 myocardial stress imaging. $\mathrm{Am}$ Cardiol 1979;44:452-8.

6 Eng C, Patterson RE, Horowitz SF, Halgash DA, Pichard $\mathrm{AD}$, Midwall J, et al. Coronary collateral function during exercise. Circulation 1982;66:309-16.

7 Kolibash AJ, Bush CA, Wepsic RA, Schroeder DP, Tetalman MR, Lewis RP. Coronary collateral vessels: spectrum of physiologic capabilities with respect to providing rest and stress myocardial perfusion, maintenance of left ventricular function and protection against infarction. Am $\mathcal{F}$ Cardiol 1982;50:230-8. 
8 McFalls EO, Araujo LI, Lammertsma AA, Rhodes CG, Bloomfield P, Pupita G, et al. Vasodilator reserve in col-
lateral-dependent myocardium as measured by positron lateral-dependent myocardium as measured by posit

9 Pupita G, Maseri A, Kaski JC, Galassi AR, Gavrielides S, Davies GJ, et al. Myocardial ischemia caused by distal coronary constriction in stable angina pectoris. $N$ Engl f Med 1990;323:514-20.

10 Mudge GH, Grossman W, Mills RM, Lesch M, Braunwald E. Reflex increase in coronary vascular resistance in patients with ischemic heart disease. N Engl Y Med 1976; 295:1333-7.

11 Nabel EG, Ganz P, Gordon JB, Alexander RW, Selwyn AP. Dilation of normal and constriction of atherosclerotic coronary arteries caused by the cold pressor test. Totic coronary arteries caused

12 Yeung AC, Vekstein VI, Krantz DS, Vita JA, Ryan TJ, Ganz $\mathrm{P}$, et al. The effect of atherosclerosis on the vasomotor response of coronary
Engl I Med 1991;325:1551-6.

13 Gregg DE, Patterson RE. Functional importance of the coronary collaterals. N Engl 9 Med 1980;303:1404-6.

14 Camici PG, Araujo LI, Spinks T, Lammertsma AA, Kaski JC, Shea MJ, et al. Increased uptake of $18 \mathrm{~F}$-fluorodeoxyglucose in post-ischemic myocardium of patients with exercise-induced angina. Circulation 1986;74:81-8.

15 Rentrop KP, Cohen M, Blanke $H$, Phillips RA. Changes in collateral channel filling immediately after controlled coronary artery occlusion by an ancioplasty balloon in human subjects. Y Am Coll Cardiol 1985;5:587-92.

16 Cole JS, Holland PA, Glaeser DH. A semiautomated technique for the rapid evaluation of left ventricular regional wall motion. Cathet Candiovasc Diagn 1976;2:185-97.

17 Spinks TJ, Jones T, Gilardi MC, Heather JD. Physical performance of the latest generation of commercial positron formance of the latest generation of commercial

18 Araujo II, Lammertsma AA, Rhodes CG, McFalls EO, Iida $\mathrm{H}$, Galassi $A$, et al. Noninvasive quantification of regional myocardial blood flow in coronary artery disease with oxygen-15-labeled carbon dioxide inhalation and positron emission tomography. Circulation 1991;83: 875-85.

19 Phelps ME, Hoffman EJ, Selin C. Investigation of $\left[{ }^{18} \mathrm{~F}\right] 2-$ fluoro-2-deoxyglucose for the measurement of myoca dial glucose metabolism. $₹$ Nucl Med 1978;19:1311-19.

20 Lammertsma AA, Brooks DJ, Fracowiak RSJ, Beaney RP, utilisation with [ $\left.{ }^{18} \mathrm{~F}\right] 2$-fluoro-2-deoxy-D-glucose: a comparison of different analytical methods. 7 Cereb Blood Flow Metab 1987;7:161-72

21 De Coster PM, Chierchia S, Davies GJ, Hackett D, Fragasso G, Maseri A. Combined effects of nitrates on the coronary and peripheral circulation in exercise- induced ischemia. Circulation 1990;81:1881-6.

22 Brown BG, Bolson E, Petersen RB, Pierce CD, Dodge HT. The mechanisms of nitroglycerin action: stenosis vasodilatation as a major component of the drug response.

23 Jones CJH, DeFily DV, Patterson JL, Chilian WM. Endothelium-dependent relaxation competes with $\alpha_{1}$ and $\alpha_{2}$-adrenergic activation in the canine coronary microcirculation. Circulation 1993;87:1264-74.

24 Harrison DG, Chilian WM, Marcus ML. Absence of functioning a-adrenergic receptors in mature canine coronary collateral circulation. Circ Res 1986;59:133-42.

25 Maruoka Y, McKiman MD, Engler RI, Longhurst JC. Functional significance of $\alpha$-adrenergic receptors in mature coronary collateral circulation of dogs. Am $f$ mature coronary collateral

26 Heusch $G$, Deussen A. The effects of cardiac sympathetic nerve stimulation on perfusion of stenotic coronary arternerve stimulation on perfusion of sten

27 Harrison DG, Sellke FW, Quillen JE. Neurohumoral regulation of coronary collateral vasomotor tone. In: Heusch G, Ross J, eds. Adrenergic mechanisms in myocardial ischemia. Darmstadt: Steinkopf Verlag, 1991:121-9.

28 Chilian WM, Layne SM, Eastham CL, Marcus MI Heterogeneous microvascular coronary $\alpha$-adrenergic vasoconstriction. Circ Res 1989;64:376-88.

29 Lamping KG, Kanatsuka H, Eastham CL, Chilian WM, Marcus MI. Nonuniform vasomotor responses of the coronary microcirculation to serotonin and vasopressin. Circ Res 1989;65:343-51.

30 Marcus MI, Chilian WM, Kanatsuka H, Dellsperger KC, Eastham CL, Lamping KG. Understanding the coronary circulation through studies at the microvascular level. Circulation 1990;82:1-7.

31 Heusch G. $a$-Adrenergic mechanisms in myocardial ischemia. Circulation 1990;81:1-13.

32 Peters KG, Marcus ML, Harrison DG. Vasopressin and the mature coronary collateral circulation. Circulation the mature coronar

33 Sellke FW, Quillen JE, Brooks LA, Harrison DG. Endothelial modulation of the coronary vasculature in vessels perfused via mature collaterals. Circulation 1990; 81:1938-47.

34 Cohen MV, Sonnenblick EH, Kirk ES. Coronary steal: its role in the detrimental effect of isoproterenol after acute coronary occlusion in dogs. Am 7 Cardiol 1976;38:880-8.

35 Harrison DG, Simonetti I. Neurohumoral regulation of collateral perfusion. Circulation 1991;83(suppl III): III62-7.

36 Gropler RJ, Siegel BA, Lee KJ, Moerlein SM, Perry DJ, Bergmann SR, Geltman EM. Nonuniformity in myocardial accumulation of fluorine-18-fluorodeoxyglucose in normal fasted humans. $\Im$ Nucl Med 1990;31:1749-56. 